\title{
Employment-oriented University-enterprise Cooperation Teaching Research_-Taking Automobile Technical Service and Marketing Specialty as an Example
}

\author{
Yanyan Shi ${ }^{1, a^{*}}$ and Ying Han ${ }^{1, b}$ \\ ${ }^{1}$ Qingdao binhai University, China \\ a471618585@qq.com, b37382430@qq.com
}

\begin{abstract}
Keywords: University-enterprise cooperation; Employment-driven; Advanced curriculum system;
\end{abstract} Training mode

\begin{abstract}
University-enterprise cooperation is a new model of innovation education in higher vocational colleges. It is a kind of joint talent training mode between schools and enterprises by using their respective advantages, sharing their education teaching resources. The new teaching mode imports enterprise standard by the cooperation between schools and enterprises. Based on the new university-enterprise cooperation teaching mode customize the employment-driven advanced curriculum system. Through learning the advanced curriculum system to cultivate students' keen market insight, improve their professional skills and professionalism. By the school-enterprise cooperation effectively improve the quality of education, meet the business needs of qualified personnel, and improve student's employment and employment quality. The high comprehensive quality meets the needs of the enterprise.
\end{abstract}

\section{First, the Significance of School-Enterprise Cooperation}

School - enterprise cooperation is a new teaching model sharing education and teaching resources, playing their respective advantages through the cooperation of schools and enterprises. School enterprise cooperation has become one of the effective measures to cultivate applied talents with high comprehensive quality and strong professional skills. Establishing school-enterprise cooperation in higher vocational colleges has very important significance to promoting school education and teaching reform .It also greatly improve the quality of employment and the rate of employment.

Firstly, school-enterprise cooperation achieve win-win situation for schools, students and enterprises. School education can closely follow the pace of market development; achieve further development through school-enterprise cooperation. Students can have more opportunities to receive education resources and skills training from enterprises and schools. Enterprises can get more excellent staff conforming their employment Standards.

Secondly, school-enterprise cooperation makes up for deficiencies of higher vocational colleges in practice education and vocational education. High school teachers universally lack abilities of enterprise management capacity and actual production capacity. They cannot accurately grasp enterprise's employment Standards in current market economy conditions. They do not timely understand the lack of labor diathesis and the adaptability for graduate students in enterprises.

School-enterprise cooperation advantageously promote the reform and innovation of talent training objectives in higher vocational colleges

Thirdly, school-enterprise cooperation can provide a real practice environment, advanced production equipment and process flow. The function and model of laboratory equipment and instruments in higher vocational colleges' Experimental Teaching Base or Training Base are frequently different from the equipment in enterprises. It is easily break away production practice of enterprises. School-enterprise cooperation can furtherly strengthen the practical skills of students in school and improve the quality of employment of graduates. 


\section{Second, Talents Training Model of School-Enterprise Cooperation in Professional of Automotive Technical Service and Marketing}

Automotive technology services and marketing professional train talents who have solid theoretical basis, application ability, professional quality and accomplishment. They are the applied Talents have high comprehensive quality, excellent professional ability in automotive sales and after-sales service areas. They are mainly engaged in production, sales, technology and after-sales service of the automotive market. They can not only operate the car, fault detection and maintenance skillfully but also apply sales and service skills expertly.

Through the talents training model of school-enterprise cooperation in the professional of automotive technical service and marketing improve students' professional ability, professional accomplishment, and also improve the employment quality of graduates and employment rate. According to school characteristics and business advantages, school - enterprise cooperation personnel training mode use dual-subject management to interact. Schools and enterprises jointly set up order classes. The order class attracts interested students to join through the form of preaching. And then screening layer by layer of written and interview test, select excellent students to join it. The order class is based on corporate standards, the automotive service market as the fundamental starting point. It combines with the professional of automotive technology services and marketing training program to participate in education and teaching, formulate talents training programs jointly. Focusing on cultivating integrated application-oriented talents with solid professional knowledge, excellent practical skills and high-quality comprehensive meet the employment standards of enterprise. It can be divided into three stages concretely. The first stage is general education stage. Students mainly complete the study of public courses and professional basic course to cultivate students' humanistic accomplishment and lay the foundation for mastery of professional courses and professional skills. The second stage is the study of professional course. This stage is mostly in college training, supplemented off-campus training. It mainly lay the theoretical foundation, strengthen the professional ability and have a certain concept of corporate culture and professional positions ability to work. Simultaneously, the company's management backbone and technical staff regularly enter school to complete the customization of business learning with students in the order class. The third stage is post practice stage. Students enter the enterprise to complete the practice of teaching content. According to company and individual needs continue to learn the relevant theoretical knowledge and expertise. This stage is mainly self-learning and enterprise-based training. Enterprise pays a certain amount of wages on the basis of company standards, bonuses and enjoys the relevant treatment.

\section{Thirdly, the Construction of Employment-Driven Advanced Curriculum System}

Under the mode of school-enterprise cooperation, schools and enterprises jointly set up the goal of talent training. And construct curriculum structure of the order class. The students not only receive professional courses offered by school, but also learn personalized courses customize by enterprise. These courses mainly include industry knowledge, corporate culture and practical training. Management, finance, supply, sales, brand belongs to the industry knowledge. Leadership, teamwork, execution belongs to the corporate culture. Store organizational structure, service processes, store marketing belongs to practical training. Excellent managers and technical staff give lessons. At the same time, the school arranges students to practice. In the post practice time, enterprises provide a sound practice environment and blameless living conditions for students. According to professional training objectives, automotive technical services and marketing professional mainly cultivate the talents can engage in automotive technical service work with automobile production services, vehicle maintenance diagnosis and testing, vehicle identification, vehicle evaluation, automotive insurance and claims. And also cultivate students' good professional ethics. They can study new technologies and knowledge related to occupation independently, have strong sense of responsibility to society, enterprises and customers. They will be high-skilled application-oriented professionals in their careers. 
The construction of professional course system integrates the task and the theoretical knowledge effectively. The course system trains students' work ability and assimilate comprehensive quality training. It can shape students' professional and technical capacity, Social capacity and method capability. According to the demand of the corporate positions, the order class customize employment-driven advanced curriculum system to cultivate professional foundation ability, Professional core competencies ability and technical comprehensive ability. The course system specific arrangements are as follows.

Firstly, according to the enterprise's desire for automobile new - type technical talent adjust part of the course content. The course focuses on automotive electronic control technology. Setting up foundation courses of automotive electronic control includes microcontroller technology, electronic sensing technology and automatic control technology. The automotive electronic control technology course sets Professional core curriculum to strengthen the students' practical ability in the automotive electronic control technology.

Secondly, according to the requirements of the core professional competence of the enterprise, add and adjust part of the course content. Vehicle fault diagnosis and detection, vehicle maintenance and repair, automotive electrical and electronic equipment integrate into a comprehensive practical course to cultivate the ability of work positions. Opening special skills core curriculum includes automobile integrated performance testing, vehicle fault diagnosis and detection, automotive engine technology and testing, automotive transmission technology and testing, vehicle driving system technology and testing, automobile steering systems and detection technology, automobile brake system technology and testing, automobile electrical and auxiliary electronic system technology and testing to train the professional and technical ability. Based on the work process customize automotive marketing courses. This course combines marketing theory knowledge with enterprise marketing practice and industry knowledge to do the targeted learning and training to lay a solid foundation for the future. For the main business of enterprises adding courses include basic knowledge of automobile tires, automotive beauty and maintenance and used car identification and evaluation to enhance and improve the professional knowledge and skills of students.

Thirdly, according to the needs of employees of professional ethics and overall quality open some courses such as automotive maintenance reception practice, automobile service enterprise management and management, marketing psychology to improve students' good professional accomplishment and the ability to solve practical problems. Schools and enterprise customize enterprise business management courses, focusing on the enterprise profile, the main business, corporate culture, marketing strategy and other aspects.

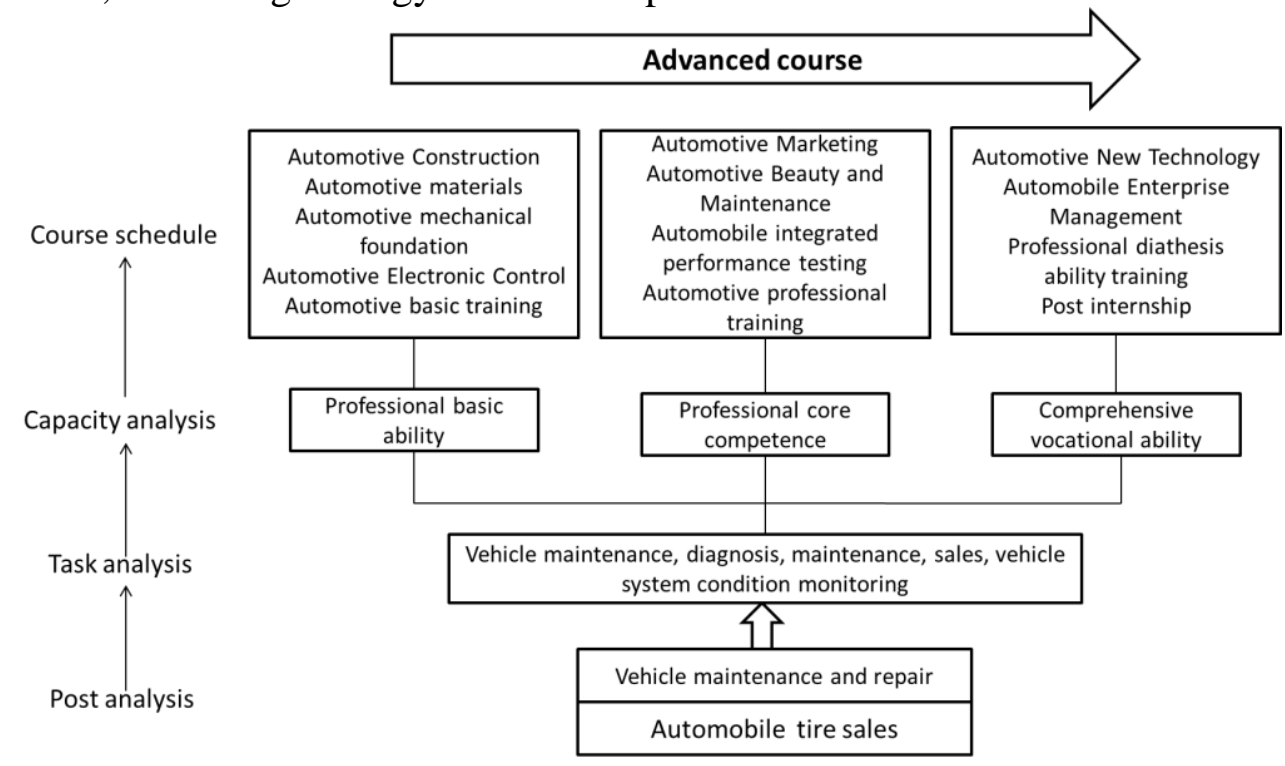

Figure 1. Employment-driven advanced curriculum system 


\section{Summary}

Through school-enterprise cooperation, the curriculum structure imports enterprise standards, adjusts and sets up some courses, establishes customized curriculum system. The teaching content is jointly developed and implemented by both parties. Course teaching is completed together by the school professional teachers, business outstanding technical backbone, management personnel. It enhances students' professional quality; cultivate students' professional foundation ability, professional core competencies and comprehensive quality ability. School-enterprise cooperation achieve a win-win situation in the true sense 。

\section{References}

[1] Yancheng Tao: Vocational \& Technical Education Forum, Vol. 23(2013), No. 3, p.65.

[2] Yuhe Zhan: High Vocational Education-Journal of Tianjin Vocational Institute, Vol.21 (2012), No.5, p.48.

[3] Chao Xu: Journal of Liaoning Provincial College of Communications, Vol 13(2011), No.3, P. 64.

[4] Guocai Zhen: Science and Technology Forum, Vol. 73(2010), No.10, p. 164.

[5] Peifu Chen, Zhiyong Yan, Ying Ji: Vocational and Technical Education, Vol. 33(2012), No.3, p.10.

[6] Wei Nie: Chinese Vocational and Technical Education, Vol. 90(2012), No. 9, p.77.

[7] He Zhen: China Higher Education Research, Vol.21 (2013), No.1, p.90.

[8] Pan Haishen, Wang shibin, Long Deyi: Higher Education of Engineering Research, Vol.20 (2013), No.3, p.143.

[9] Lin Jian: Higher Education of Engineering Research, Vol.16 (2012), No.3, p.7.

[10]Zhu Cuilin: Higher Education Forum, Vol.19 (2014), No.2, p.36. 